\title{
Risk of introducing viral hemorrhagic septicemia virus (VHSV) to the Chilean South Pacific via sardine imports from Europe
}

\author{
Luis Pablo Hervé-Claude ${ }^{1}$, Tim E. Carpenter ${ }^{1,2, *}$, Ronald P. Hedrick $^{1}$ \\ ${ }^{1}$ Department of Medicine and Epidemiology, School of Veterinary Medicine, University of California, Davis, \\ California 95616, USA \\ ${ }^{2}$ Center for Animal Disease Modeling and Surveillance (CADMS), School of Veterinary Medicine, University of California, \\ Davis, California 95616, USA
}

\begin{abstract}
Chile imports from Spain 100s of metric tons of frozen sardine Sardina pilchardus fished in European oceans, which, with several other clupeids, are presumed susceptible to infection with viral hemorrhagic septicemia virus (VHSV). The frozen sardines are directly introduced into the sea as bait to catch southern hake Merluccius australis in the same areas where wild and pen-raised salmonids are present. A simulation model was therefore developed to evaluate the potential risk of infection of wild Chilean southern hake with VHSV from imported bait. The model indicated that VHSV-susceptible fish species present in Chilean waters, like southern hake, are not at immediate risk of infection. However, sensitivity analyses showed that infectious doses at lower concentrations of VHSV combined with higher VHSV-prevalence import scenarios could likely result in VHSV

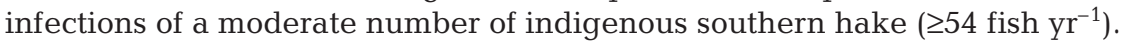

KEY WORDS: Bait fish $\cdot$ Sardine $\cdot \mathrm{VHSV} \cdot$ Freezing $\cdot$ Salmon $\cdot$ Risk assessment Resale or republication not permitted without written consent of the publisher

\section{INTRODUCTION}

Viral hemorrhagic septicemia virus (VHSV) has been identified in many marine finfish from both the Atlantic and Pacific Oceans (Meyers \& Winton 1995, Skall et al. 2005b). This rhabdovirus has also been identified in fish from European waters, mostly from the North and Baltic Seas (Stone et al. 1997, King et al. 2001b, Skall et al. 2005a). VHSV is associated with a disease of major importance to finfish aquaculture (Anonymous 1991), which can have devastating effects on fish farms, particularly those with rainbow trout Oncorhynchus mykiss. Significant impacts of the virus have also been recently observed among wild populations of freshwater fish in eastern Canada and the Great Lakes region of North America (Elsayed et al. 2006, Gagné et al. 2007). The disease (viral hemorrhagic septicemia, VHS) associated with VHSV infection is characterized by edema and hemorrhage in multiple organs, impairment of osmotic balance and eventually death (OIE 2001). Viral infection is influenced by water temperature, both in sea and fresh water, with disease outbreaks reported between 4 and $15^{\circ} \mathrm{C}$, although virus replication extends to temperatures between 4 to $20^{\circ} \mathrm{C}$ (Wolf 1988). At water temperatures $>20^{\circ} \mathrm{C}$, virus infections are restricted, with clinical disease, if present, generally taking a short course with a modest cumulative mortality (OIE 2001).

More than 45 species of marine and freshwater fish have been identified as susceptible to VHSV infection (OIE 2001) and the list is steadily increasing (Skall et al. 2005b) with the potential that all marine fish are susceptible (Stone et al. 1997). This list includes rainbow trout (Einer-Jensen et al. 2004), Atlantic salmon Salmo salar (de Kinkelin \& Castric 1982), Pacific hake Merluccius productus (Meyers et al. 1999), and members of the family Clupeidae, such as Atlantic herring Clupea harengus sp. (Dixon et al. 1997, Mortensen et 
al. 1999), a species imported into Chile as bait. As most clupeids that have been examined are susceptible to VHSV, the sardine Sardina pilchardus is also presumed susceptible.

Spain is one of the biggest exporters of sardine to Chile, whose fleet, according to the Chilean Fisheries Service (Sernapesca), catches sardine in both the Mediterranean Sea and in the North Atlantic (H. Mansilla pers. comm.). Sardina pilchardus is a migratory species with a distribution ranging from Senegal in the south to the Baltic and North Seas to the north (Gennari \& Tomaselli 1988, Parrish et al. 1989, Voulgaridou \& Konstantinos 2003). The migratory patterns have not yet been completely clarified (Atarhouch et al. 2006). In some areas in the North and Baltic Seas, many species including clupeids have been found to be infected with VHSV (Mortensen et al. 1999, Smail 2000, Skall et al. 2005a). Although officially declared by the OIE (World Organization for Animal Health) free of VHSV infection, there have been reports of VHSV isolated from Atlantic salmon and other fish species in Spain (Basurco \& Coll 1992, López-Vázquez et al. 2003). Most VHSV surveillance programs focus on freshwater fish in commercial aquaculture facilities, not marine species such as sardine. For marine species, fishing activities are usually in international waters, where little or no surveillance occurs.

According to Sernapesca (Servicio Nacional de Pesca), an average of more than 1400 metric tons (t) of frozen Sardinus pilchardus, a presumed susceptible species, have been imported from Spain from 2002 through 2005 and introduced annually into Chilean waters, where temperatures are commonly below $12^{\circ} \mathrm{C}$ (Centro Nacional de Datos Hidrográficos y Oceanográficos de Chile, available at: http://www.shoa.cl/ cendhoc_php/index.htm; C. Jara pers. comm.). Sardine are used as bait for the local Southern hake Merluccius australis fishery, which employs the long-line capture method (Sierpe \& Sanhueza 2003). Therefore, the risk of introducing VHSV to the wild southern hake as well as salmonid populations should be considered. Wild salmonid populations of the brown trout Salmo trutta, rainbow trout and Atlantic salmon are present in the Chilean South Pacific (Iriarte et al. 2005) and are all underreported as bycatch of the small-scale southern hake fishery (C. Jara pers. comm.).

Depending on the scenario, the introduction of VHSV could pose a serious risk to the large South American Atlantic salmon industry (Skall et al. 2005b). Our study uses a risk assessment, which is an evaluation of the likelihood of entry, establishment or spread of disease within the territory of an importing country (World Trade Organization 1995; www.wto.org), to estimate the probability of VHSV infection of hake and wild salmonids in Chile under different bait fish import scenarios.

\section{MATERIALS AND METHODS}

Bait sardine imports, viral concentration and VHSV prevalence. Records of sardine bait imports into Chile for 2005 were obtained from the Chilean Fisheries Service. Information for the 2005 imports from Spain (859 t, 35\% of total bait imports) was used to evaluate the import scenario. Spain was selected because it is the main exporter of bait sardine to Chile. This fishery is located in the Spanish territorial waters in the Mediterranean Sea, in the region of Murcia and on the Atlantic and North Atlantic oceans. VHSV has never been isolated from fish in the Mediterranean Sea although it is present among fish in the Atlantic Ocean (Basurco \& Coll 1992, López-Vázquez et al. 2003). Therefore, imports from the Mediterranean Sea and the Atlantic and North Atlantic oceans were considered as a very low within-batch prevalence $(0.1 \%)$ scenario.

Simulations were performed using EXCEL and 2 spreadsheet add-ins, TreePlan ${ }^{\circledR}$ (Middleton) and @RISK $^{\circledR}$ (Palisade). To perform the simulation, it was assumed that for each scenario all of the imported bait originated from one prevalence area. Generally speaking, prevalence calculations should be viewed with caution, as sampling of fish will never be totally random and the prevalence may differ with each fish population (Skall et al. 2005b). Virus concentration estimates among individuals in the fish population in these prevalence areas were obtained through personal communication (R. P. Hedrick unpubl. data) and determined to have a Pearson5 distribution (RiskPearson5; 3,20000 ), with a mode of $5 \times 10^{3}$ plaque forming units $\left(\mathrm{pfu} \mathrm{g}^{-1}\right.$ ) and mean of $1 \times 10^{4} \mathrm{pfu}^{-1}$. This distribution was chosen for its shape and output, giving high numbers of low VHSV-concentration fish while simultaneously allowing low numbers of high VHSV-concentration fish.

Based on reported VHSV survival after commercial freezing (Arkush et al. 2006), a triangular distribution provided the best estimate of the percentage decrease of VHSV-infectious units in sardine after freezing and thawing, with a minimum, most likely and maximum decrease of 63.8, 100 and $100 \%$, respectively (RiskTriangular; 63.8, 100, 100). The information was obtained using @ RISK $^{\circledR}$ after log transformation and analysis of published data (Arkush et al. 2006). These distributions were used to estimate amount of infective sardine that reach Chilean waters. By recording the proportion of bait sardine that retained a VHSV concentration equal to or higher than the concentration used by Ahne (1980) of $2 \times 10^{5} \mathrm{pfu}^{-1}$ to infect the pike Esox lucius, the proportion of infective sardine was calculated. 
The mean number of frozen sardine $\mathrm{kg}^{-1}$ was reported as 10 , but could differ slightly depending on the fish size (H. Mansilla pers. comm.). The reported survival under frozen conditions of VHSV and a shrimp rhabdovirus for at least 2 wk (Wolf 1988, Lu \& Loh 1992, Arkush et al. 2006) and for considerably longer at $-20^{\circ} \mathrm{C}$ or lower temperatures (Wolf 1988, Lu \& Loh 1992) suggested that thawing and not duration of the storage is the key factor for VHSV mortality. In fact, freezing at temperatures varying from -20 to $-80^{\circ} \mathrm{C}$ to preserve VHSV in fish for up to 2 mo has been reported (Mortensen et al. 1999, King et al. 2001b, Dixon et al. 2003). Therefore, duration of storage was excluded from the analysis.

Simulation model. A simulation model was constructed to evaluate the risk of VHSV introduction by means of infected bait imported to the XIIth region of Chile. The model simulated the following scenario: bait sardine are fished in the Mediterranean Sea and on the Atlantic and North Atlantic oceans. Shortly afterwards, bait is frozen and transported by sea to Chile. Bait is received and stored (generally for less than $3 \mathrm{mo}$ ) in various locations in the XIIth region of Chile prior to use. Overall, commercial freezing diminishes the number of infectious VHSV in fish tissues; however, this effect may vary from fish to fish (Arkush et al. 2006). Bait is sold mainly to the large-scale fishery and the remainder to the small-scale fishery. Both fisheries set baited hooks in the ocean; after several hours, hooks are recovered and the remaining bait is discarded into the sea. Two main species were considered at risk of feeding on infected fish bait: southern hake (the target species of the fish industry), and wild salmonids (an incidental species). The risk of infection was determined for both species in the small-scale fishery scenario and only for southern hake in the large-scale scenario. Each simulation represents the yearly probability of infection of each fish species.

The model is based on the following assumptions:

(1) Fish bait is imported from a $0.1 \%$ VHSVprevalence area.

(2) A bait shipment is a random sample of the VHSV prevalence in the defined prevalence area. All bait shipments are by sea and under frozen conditions.

(3) Infectious sardine are VHSV-infected with a VHSV concentration $\geq 2 \times 10^{5} \mathrm{pfu} \mathrm{g}^{-1}$ (Ahne 1980), estimated prior to freezing. A reduction proportion (Risk Triangular; 63.8, 100, 100) (Arkush et al. 2006) was applied to calculate the proportion of infective sardine after freezing and thawing.

(4) All imported bait is used in the mentioned industries either by small- or large-scale southern hake fisheries based in Chile. One percent of imported fish bait is used by the small-scale fishery (H. Mansilla pers. comm.).
(5) Bait is used throughout the year without any seasonal changes. Fishing activities are performed regularly through the year.

(6) In the large-scale fishery, bait is consumed either by southern hake, 50 to $99 \%$ of the time (Uniform; 0.50, 0.99), with a mean proportion of 0.745 (High 1980, He 1996), or by non-susceptible scavengers and seagulls (Collins 1999). In the small-scale fishery, besides southern hake consumption (Uniform; 0.50, 0.99), bait is consumed by wild salmonids, (Uniform; 0.00, 0.01); H. Mansilla pers. comm.), with a mean proportion of 0.005 , and the remainder by scavengers and seagulls.

(7) Non-susceptible species exposed to infective bait will not be infected by VHSV. It was reported that $30 \%$ of fish exposed to a concentration of $2 \times 10^{5} \mathrm{pfu}^{-1}$ of VHSV will become infected through the oral route (Ahne 1980). A uniform distribution of between 15 to $45 \%$ (RiskUniform; $0.15,0.45$ ) of susceptible species exposed to VHSV-infectious fish bait will be infected by the virus to reflect the uncertainty of data obtained from an experimental exposure of a fish species other than southern hake.

(8) Each studied fish (southern hake or salmonid) will only feed upon one fish bait per time period (yr). This conservative assumption was made due to the lack of information about this topic.

The impact was assessed in terms of individual probability and number of each species (southern hake or wild salmonids) of fish in Chile infected per year by the use of this fish bait. A binomial distribution was used to estimate the number of fish infected with VSHV:

$$
f(x)\left(\frac{n}{x}\right) p^{x}(1-p)^{n-x}
$$

where $p$ is the probability that a given fish will become infected via VHSV-infected sardine consumption during a 1 yr period, $n$ is the number of bait sardine imported in 2005 and $x$ is the number of fish infected. Based on the assumption that there were 8.59 million sardine in 2005, a total of 8.59 million southern hake and wild salmonids were presumed at risk of infection that year.

A total of 100000 iterations using Monte Carlo sampling with @ RISK $^{\circledR}$ were performed. Results were tabulated and reported for most scenarios as annual probability of fish becoming infected with VHSV and probability of infecting one or more fish per scenario.

Decision tree. The above information was used to create a decision tree using TreePlan ${ }^{\circledR}$ (Fig. 1). Once constructed, the tree was used to obtain individual infection probabilities and probability of infecting at least one fish for both fisheries scenarios (large- and small-scale) and susceptible species: southern hake and wild salmonids in the small-scale scenario and southern hake only in the large-scale scenario. 
Sensitivity analysis. Sensitivity analyses were performed to evaluate if modifications to the original assumptions had a measurable effect on the yearly risk of infecting southern hake or wild salmonids in the south of Chile. Analyses were performed for 8 additional scenarios: 3 VHSV-prevalence areas, 2 infectivebait post-freezing proportions that consider lower required VHSV concentrations to infect fish and 3 imported bait proportions used by the small-scale fishery with 10000 iterations each.

The initial risk scenario assumed a VHSV prevalence among sardine caught for bait of $0.1 \%$. An additional 3 scenarios were examined to reflect higher VHSV prevalence in bait fish originating from the North or Baltic Sea fisheries (Skall et al. 2005b). VHSV-prevalence estimates in the Mediterranean and other European seas for differ- ent sardine species were obtained from prior studies. The moderate-low prevalence scenario was located in the North Sea, with a reported prevalence of about $1 \%$ in herring (King et al. 2001b). A hypothetical moderate risk scenario was created with a prevalence of $8 \%$ and the high-risk scenario simulated sardine Clupea harengus captured in the Baltic Sea, where a prevalence of $16.7 \%$ was reported (Skall et al. 2005a).

Two alternative scenarios were examined, with 10000 iterations each, to address the potential underestimation of the concentration needed to infect southern hake and wild salmonids. The alternatives assumed either a $1 \times 10^{5}$ or $2 \times 10^{4} \mathrm{pfu} \mathrm{g}^{-1}$ (5- and 10 fold reduction, respectively) of VHSV concentration to infect fish, and resulted in infectious post-freezing proportions of 0.0011 and 0.0803 , respectively.

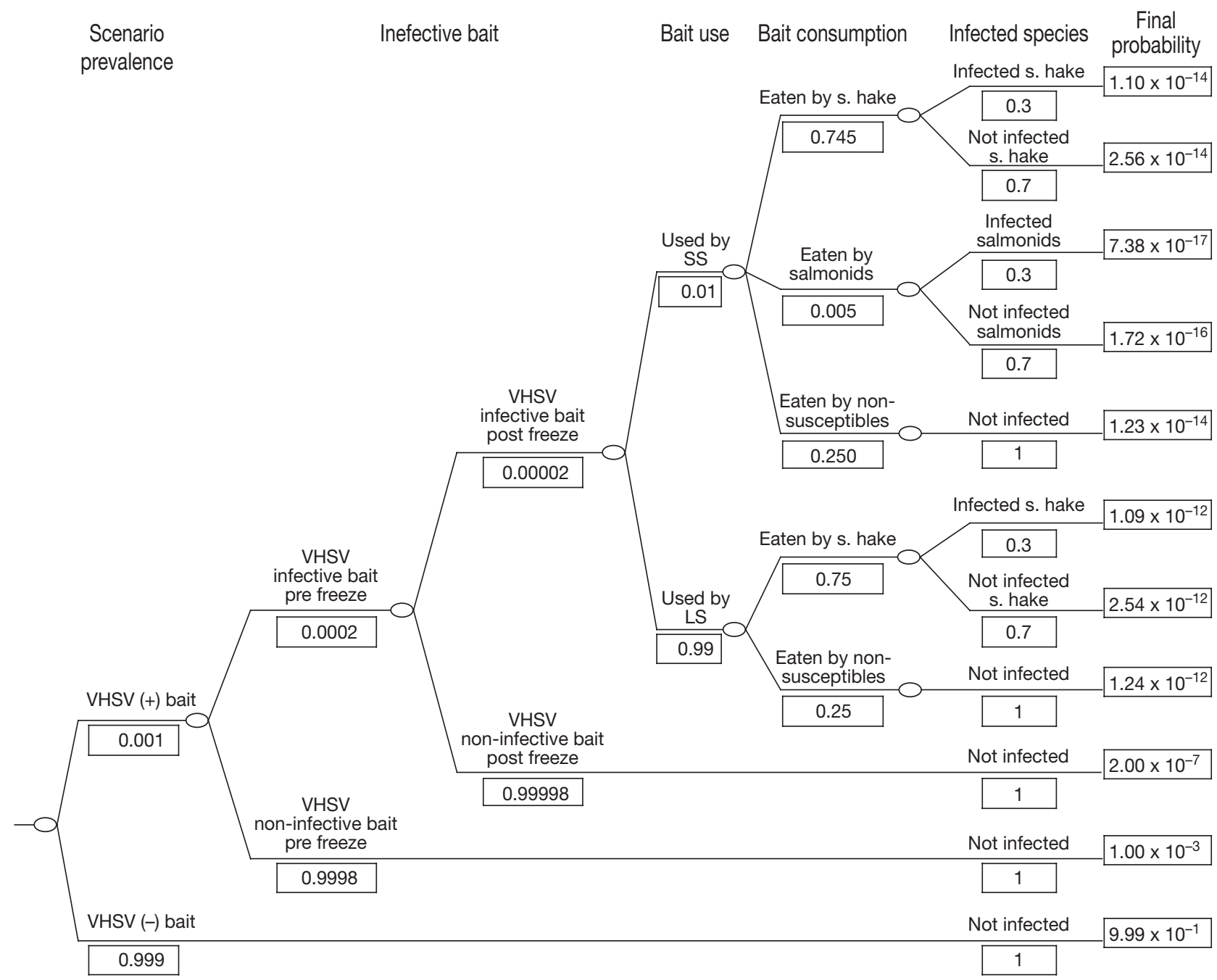

Fig. 1. Decision tree (without values) of both southern hake Merluccius australis (s. hake) and wild salmonids (Oncorhynchus mykiis, Salmo trutta and S. salar) infection probability with viral hemorrhagic septicemia virus (VHSV) in the Chilean South Pacific through the import and use of VHSV-infected fish bait for the commercial southern hake long-line large-scale (LS) or small-scale (SS) fisheries. In practice, each rectangle is filled by either a point estimator or distribution, and expected probabilities below each outcome are given at the right end of each branch 
A variable small bait proportion is bought and used by the small-scale fishery. For this reason, the imported bait proportion used by the small-scale fishery was increased from the initial value of 0.01 to $0.025,0.05$ and to 0.10 in 3 different scenarios.

\section{RESULTS}

After freezing and according to the distributions used, a proportion of only $2.46 \times 10^{-5}, 95 \%$ probability interval (PI) $\left(0-5.72 \times 10^{-5}\right)$ of the VHSV-infected sardine remained infective, over the presumed infective dose of $2 \times 10^{5} \mathrm{pfu} \mathrm{g}^{-1}$. The incidence proportion for the different species in the large- and small-scale scenarios and the probability of infecting at least one fish are shown in Table 1. Considering these initial assumptions, including current import conditions, the expected number of imported VHSV-infective fish bait after freezing and thawing was extremely low, as was the probability of infecting at least 1 fish $\mathrm{yr}^{-1}$.

\section{Sensitivity analysis}

Wild salmonids had a lower probability than southern hake of becoming infected with VHSV throughout the study due to their relatively low exposure. Salmonid infection probabilities were extremely low in all but the worst case scenario, which included a high prevalence import area and a required VHSVinfectious concentration 10-fold lower than used in the initial model. Results for 4 different small-scale bait use scenarios are shown in Fig. 2. Coincidently, southern hake populations had a low risk of becoming infected by the small-scale industry.

From the variables studied, the model was most sensitive to the assumed VHSV concentration required to infect fish. In contrast, the model was relatively insensitive to initial VHSV prevalence and use of bait by the

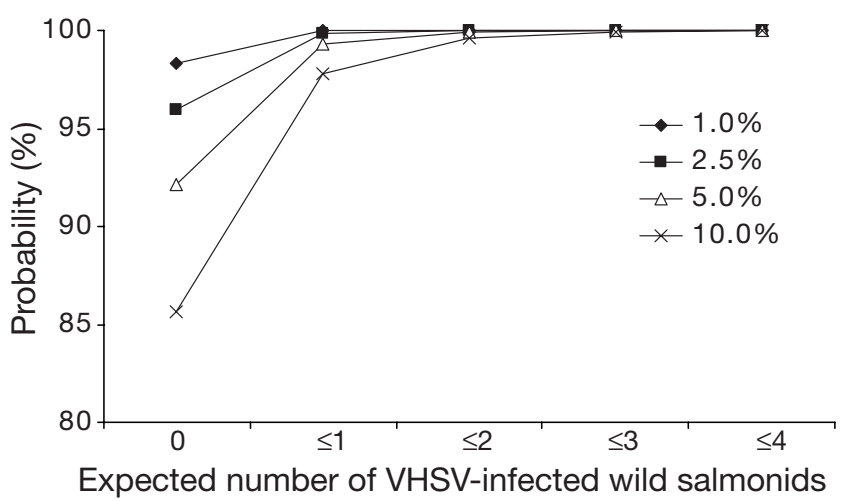

Fig. 2. Oncorhynchus mykiis, Salmo trutta and S. salar. Annual cumulative density function of the expected number of wild salmonids infected by bait used at the small-scale long-line southern hake fishery in the Chilean South Pacific after yearly imports of $859 \mathrm{t}$ of bait sardines in 4 different small-scale bait use scenarios. Results shown consider catch from a $16.7 \%$ viral hemorrhagic septicemia virus (VHSV) prevalence area; $8.03 \%$ of VHSV-infected bait will remain infective after commercial freezing, transport by sea and thawing prior use in Chile, and a VHSV concentration of $2 \times 10^{4} \mathrm{pfu} \mathrm{g}^{-1}$ is needed to infect wild salmonids

small-scale fishery, changes to which produced almost no variation in the overall results. Results for potential infected southern hake due to large-scale fishing activities are shown in Table 2. The worst case scenario indicates that there is approximately a $25 \%$ probability that no southern hake will be infected annually in the Chilean South Pacific by the small-scale fishery due to imports from high VHSV-prevalence areas if the VHSV concentration needed to infect fish were $2 \times$ $10^{4} \mathrm{pfu} \mathrm{g}^{-1}$ (Fig. 3). Furthermore, under these assumptions, the probability of infecting 10 or more southern hake is approximately zero, i.e. the probability of infecting fewer than 10 is approximately 100\%. In addition, there is a 0 to $18 \%$ probability of infecting 0 to 54 southern hake per year, respectively, in the Chilean South Pacific by the large-scale fishery due to imports from high VHSV-prevalence areas if the

Table 1. Mean yearly proportion and probability (95\% probability interval) of infecting southern hake Merluccius australis and wild salmonids (Oncorhynchus mykiis, Salmo trutta and S. salar) in the Chilean South Pacific with viral hemorrhagic septicemia virus (VHSV) through the import and use of VHSV-infected imported fish bait in the small- and large-scale commercial southern hake long-line fisheries

\begin{tabular}{|llll|}
\hline Fishery scale & Species & $\begin{array}{l}\text { Mean proportion } \\
(95 \% \text { PI) }\end{array}$ & $\begin{array}{l}\text { Mean probability of } \\
\text { infecting } \geq 1 \text { fish }(95 \% \text { PI) }\end{array}$ \\
\hline Large & Southern hake & $1.09 \times 10^{-12}$ & $5.12 \times 10^{-5}$ \\
& & $\left(7.54 \times 10^{-14} ; 2.93 \times 10^{-12}\right)$ & $\left(6.82 \times 10^{-7} ; 2.53 \times 10^{-5}\right)$ \\
Small & Southern hake & $1.10 \times 10^{-14}$ & $\left(6.09 \times 10^{-7}\right.$ \\
& & $\left(7.65 \times 10^{-16} ; 2.94 \times 10^{-14}\right)$ & $\left.4.77 \times 10^{-9} ; 2.54 \times 10^{-7}\right)$ \\
& Wild salmonids & $7.46 \times 10^{-17}$ & $\left(0 ; 1.91 \times 10^{-9}\right)$ \\
\hline
\end{tabular}


Table 2. Merluccius australis. Sensitivity analyses of the mean yearly infection proportion and probability (95\% probability interval, PI) of infecting southern hake in the Chilean South Pacific with viral hemorrhagic septicemia virus (VHSV) through the import and use of VHSV-infected fish bait for the large-scale commercial long-line southern hake fishery (assuming 2005 frozen fish bait import conditions of $859 \mathrm{t} \mathrm{yr}^{-1}$ )

\begin{tabular}{|c|c|c|c|c|}
\hline $\begin{array}{l}\text { Prevalence } \\
\text { scenario }\end{array}$ & $\begin{array}{l}\text { Infective after } \\
\text { freezing proportion }\end{array}$ & $\begin{array}{l}\text { Small-scale use } \\
\text { proportion }\end{array}$ & $\begin{array}{l}\text { Mean infection proportion } \\
\qquad(95 \% \mathrm{PI})\end{array}$ & $\begin{array}{l}\text { Probability of infecting } \geq 1 \text { fish } \\
\qquad(95 \% \mathrm{PI})\end{array}$ \\
\hline \multirow[t]{3}{*}{$0.1 \%$} & 0.0002 & 0.10 & $9.86 \times 10^{-13}\left(6.31 \times 10^{-14} ; 2.62 \times 10^{-12}\right)$ & $8.47 \times 10^{-6}\left(5.42 \times 10^{-7} ; 2.25 \times 10^{-5}\right)$ \\
\hline & 0.0011 & $\begin{array}{l}0.01 \\
0.10\end{array}$ & $\begin{array}{l}3.28 \times 10^{-11}\left(2.06 \times 10^{-12} ; 8.76 \times 10^{-11}\right) \\
3.01 \times 10^{-11}\left(1.97 \times 10^{-12} ; 7.88 \times 10^{-11}\right)\end{array}$ & $\begin{array}{l}2.84 \times 10^{-4}\left(1.77 \times 10^{-5} ; 7.52 \times 10^{-4}\right) \\
2.58 \times 10^{-4}\left(1.69 \times 10^{-5} ; 6.77 \times 10^{-4}\right)\end{array}$ \\
\hline & 0.0803 & $\begin{array}{l}0.01 \\
0.10\end{array}$ & $\begin{array}{l}1.74 \times 10^{-7}\left(1.06 \times 10^{-8} ; 4.61 \times 10^{-7}\right) \\
1.60 \times 10^{-7}\left(1.12 \times 10^{-8} ; 4.20 \times 10^{-7}\right)\end{array}$ & $\begin{array}{l}6.28 \times 10^{-1}\left(8.68 \times 10^{-2} ; 9.81 \times 10^{-1}\right) \\
6.11 \times 10^{-1}\left(9.19 \times 10^{-2} ; 9.73 \times 10^{-1}\right)\end{array}$ \\
\hline \multirow[t]{3}{*}{$1.0 \%$} & 0.0002 & $\begin{array}{l}0.01 \\
0.10\end{array}$ & $\begin{array}{l}1.08 \times 10^{-11}\left(6.88 \times 10^{-13} ; 2.84 \times 10^{-11}\right) \\
9.82 \times 10^{-12}\left(6.64 \times 10^{-13} ; 2.60 \times 10^{-11}\right)\end{array}$ & $\begin{array}{l}9.31 \times 10^{-5}\left(5.91 \times 10^{-6} ; 2.44 \times 10^{-4}\right) \\
8.43 \times 10^{-5}\left(5.70 \times 10^{-6} ; 2.23 \times 10^{-4}\right)\end{array}$ \\
\hline & 0.0011 & $\begin{array}{l}0.01 \\
0.10\end{array}$ & $\begin{array}{l}3.30 \times 10^{-10}\left(2.14 \times 10^{-11} ; 8.82 \times 10^{-10}\right) \\
3.02 \times 10^{-10}\left(2.06 \times 10^{-11} ; 7.93 \times 10^{-10}\right)\end{array}$ & $\begin{array}{l}2.84 \times 10^{-3}\left(1.84 \times 10^{-4} ; 7.55 \times 10^{-3}\right) \\
2.59 \times 10^{-3}\left(1.77 \times 10^{-4} ; 6.79 \times 10^{-3}\right)\end{array}$ \\
\hline & 0.0803 & $\begin{array}{l}0.01 \\
0.10\end{array}$ & $\begin{array}{ll}1.78 \times 10^{-6} & \left(1.21 \times 10^{-7} ; 4.67 \times 10^{-6}\right) \\
1.61 \times 10^{-6} & \left(1.05 \times 10^{-7} ; 4.29 \times 10^{-6}\right)\end{array}$ & $\begin{array}{l}9.53 \times 10^{-1}\left(6.46 \times 10^{-1} ; 1.00\right) \\
9.46 \times 10^{-1}\left(5.94 \times 10^{-1} ; 1.00\right)\end{array}$ \\
\hline \multirow[t]{3}{*}{$8.0 \%$} & 0.0002 & $\begin{array}{l}0.01 \\
0.10\end{array}$ & $\begin{array}{l}8.80 \times 10^{-11}\left(5.48 \times 10^{-12} ; 2.32 \times 10^{-10}\right) \\
7.92 \times 10^{-11}\left(5.65 \times 10^{-12} ; 2.11 \times 10^{-10}\right)\end{array}$ & $\begin{array}{l}7.55 \times 10^{-4}\left(4.71 \times 10^{-5} ; 1.99 \times 10^{-3}\right) \\
6.80 \times 10^{-4}\left(4.86 \times 10^{-5} ; 1.81 \times 10^{-3}\right)\end{array}$ \\
\hline & 0.0011 & $\begin{array}{l}0.01 \\
0.10\end{array}$ & $\begin{array}{ll}2.65 \times 10^{-9} & \left(1.78 \times 10^{-10} ; 7.03 \times 10^{-9}\right) \\
2.38 \times 10^{-9} & \left(1.56 \times 10^{-10} ; 6.40 \times 10^{-9}\right)\end{array}$ & $\begin{array}{l}2.24 \times 10^{-2}\left(1.53 \times 10^{-3} ; 5.86 \times 10^{-2}\right) \\
2.01 \times 10^{-2}\left(1.34 \times 10^{-3} ; 5.35 \times 10^{-2}\right)\end{array}$ \\
\hline & 0.0803 & $\begin{array}{l}0.01 \\
0.10\end{array}$ & $\begin{array}{ll}1.41 \times 10^{-5} & \left(9.42 \times 10^{-7} ; 3.72 \times 10^{-5}\right) \\
1.28 \times 10^{-5} & \left(8.08 \times 10^{-7} ; 3.40 \times 10^{-5}\right)\end{array}$ & $\begin{array}{l}9.99 \times 10^{-1}\left(9.99 \times 10^{-1} ; 1.00\right) \\
9.99 \times 10^{-1}\left(9.99 \times 10^{-1} ; 1.00\right)\end{array}$ \\
\hline \multirow[t]{3}{*}{$16.7 \%$} & 0.0002 & $\begin{array}{l}0.01 \\
0.10\end{array}$ & $\begin{array}{l}1.81 \times 10^{-10}\left(1.21 \times 10^{-11} ; 4.77 \times 10^{-10}\right) \\
1.69 \times 10^{-10}\left(1.10 \times 10^{-11} ; 4.41 \times 10^{-10}\right)\end{array}$ & $\begin{array}{l}1.55 \times 10^{-3}\left(1.04 \times 10^{-4} ; 4.09 \times 10^{-3}\right) \\
1.45 \times 10^{-3}\left(9.43 \times 10^{-5} ; 3.78 \times 10^{-3}\right)\end{array}$ \\
\hline & 0.0011 & $\begin{array}{l}0.01 \\
0.10\end{array}$ & $\begin{array}{ll}5.53 \times 10^{-9} & \left(3.59 \times 10^{-10} ; 1.49 \times 10^{-8}\right) \\
5.01 \times 10^{-9} & \left(3.42 \times 10^{-10} ; 1.32 \times 10^{-8}\right)\end{array}$ & $\begin{array}{l}4.57 \times 10^{-2}\left(3.08 \times 10^{-3} ; 1.20 \times 10^{-1}\right) \\
4.15 \times 10^{-2}\left(2.94 \times 10^{-3} ; 1.07 \times 10^{-1}\right)\end{array}$ \\
\hline & 0.0803 & $\begin{array}{l}0.01 \\
0.10\end{array}$ & $\begin{array}{ll}2.97 \times 10^{-5} & \left(2.06 \times 10^{-6} ; 7.78 \times 10^{-5}\right) \\
2.70 \times 10^{-5} & \left(1.94 \times 10^{-6} ; 7.17 \times 10^{-5}\right)\end{array}$ & $\begin{array}{l}9.99 \times 10^{-1}\left(9.99 \times 10^{-1} ; 1.00\right) \\
9.99 \times 10^{-1}\left(9.99 \times 10^{-1} ; 1.00\right)\end{array}$ \\
\hline
\end{tabular}

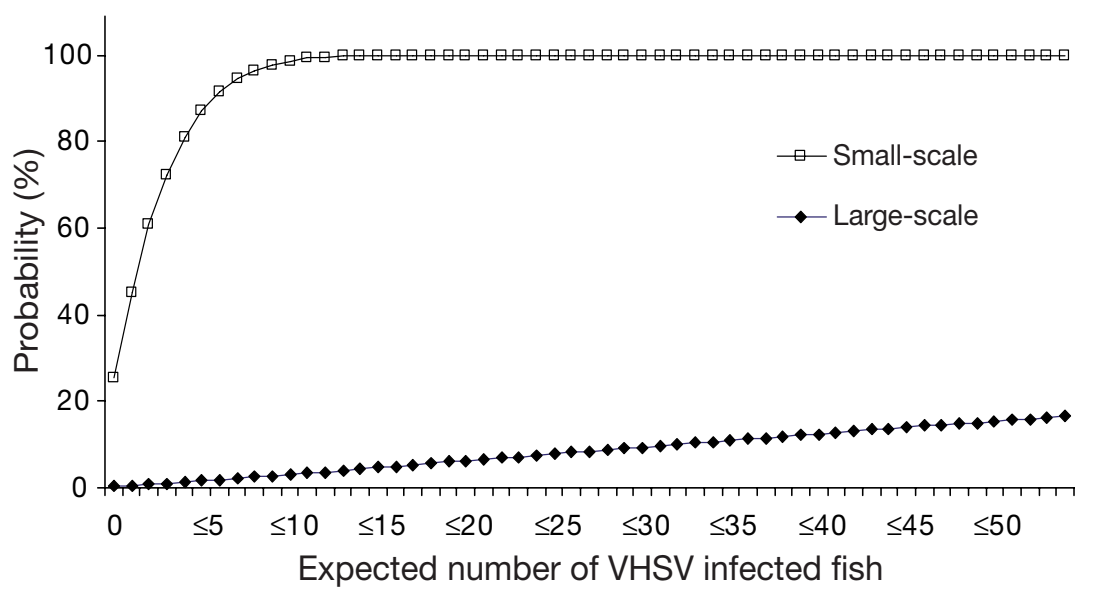

Fig. 3. Merluccius australis. Worst case scenario annual cumulative density function. Expected number of southern hake infected by bait used at the smalland large-scale long-line southern hake fisheries in the Chilean South Pacific after yearly import and use of $859 \mathrm{t}$ of bait sardines. Results shown consider catch from a $16.7 \%$ viral hemorrhagic septicemia virus (VHSV) prevalence area; $8.03 \%$ of VHSV-infective bait will remain infective after commercial freezing, transport by sea and thawing prior use in Chile; VHSV concentration of $2 \times 10^{4} \mathrm{pfu} \mathrm{g}^{-1}$ is needed to infect southern hake and $1 \%$ of imported fish bait is used by the small-scale industry
VHSV concentration needed to infect fish were $2 \times 10^{4} \mathrm{pfu}^{-1}$. In this scenario, there is an $82 \%$ probability that more than 54 southern hake will be infected. Due to software limitations it was not possible to estimate the number of infected fish greater than 54 .

\section{DISCUSSION}

In this study, the distribution of VHSV concentrations likely to be found among infected fish populations was estimated. Subsequently, the number of infective fish bait introduced to Chile was calculated as was the potential number of southern hake and wild salmonids likely to be infected per year as a result of this bait import. Few fish were estimated to become infected with VHSV under 
the different risk scenarios examined. This is consistent with the lack of reports of VHS outbreaks in Chile and Australia (OIE World Animal Health Organization Database Interface 2007, available at: www.oie.int/ wahid-prod/public.php), both of which import large numbers of bait sardine. The VHSV concentration used to determine whether the virus concentration in fish bait was sufficient to infect southern hake (a fish of suspected susceptibility to VHSV infection; Stone et al. 1997) was extrapolated from that known for pike Esox lucius under environmental conditions that may differ from those found in Chile (Ahne 1980). Different scenarios with lower VHSV concentrations required to infect fish were created to address this uncertainty.

Infection and subsequent mortality of pike through ingestion of rainbow trout with VHSV concentrations of 2 $\times 10^{5} \mathrm{pfu} \mathrm{g}^{-1}$ have been demonstrated (Ahne 1980). The cumulative percent mortality among pike infected by this oral route was $30 \%$, and the infection percentage was likely much greater. Thus, the VHSV concentrations in the trout fed to the pike should be viewed as an upper limit required to induce mortality rather than an accurate measure of subsequent infection status in fish exposed to the virus via the ingestion route, which likely occurs at substantially lower VHSV concentrations. Furthermore, the study of Ahne (1980) utilized a freshwater fish VHSV isolate, and experimental exposures were conducted in a freshwater fish species. Different host-virus outcomes might be anticipated with marine virus isolates and marine fish (King et al. 2001a, Skall et al. 2005b). VHSV isolates from marine fish are routinely less virulent for salmonids than isolates from freshwater fish. In contrast, marine isolates of VHSV may be highly pathogenic to marine fish. Kocan et al. (1997) demonstrated that a concentration of $32 \mathrm{pfu} \mathrm{g}^{-1}$ of a genotype IVa VHSV was sufficient to infect and induce a cumulative mortality of $80 \%$ among laboratory-reared Pacific herring Clupea pallasi. We presume the oral route would be the principal route of infection of southern hake or wild salmonids in Chile by bait fish; however, data on the doses required for infection are currently unknown. If virus doses considerably less that $2 \times 10^{5} \mathrm{pfu}^{-1}$ are capable of infecting southern hake or wild salmonids, the expected proportion of infective fish bait after freezing would be higher, as shown in the different risk scenarios evaluated in this study (Figs. $2 \& 3$ ).

\section{Likelihood of a VHSV introduction to Chile}

The use of infected fish for feed or bait poses a serious risk of introducing disease to both wild and farmed aquatic species (Meyers et al. 1994, Goodwin et al. 2004, Skall et al. 2005b). Despite this risk, to date there has been no reported transmission of VHSV through the use of fish bait in the pelagic fisheries in Chile. Australia, one of the largest importers of fish bait, imports much greater amounts of frozen sardine than Chile as bait for the pen-rearing of tuna. These imports have been estimated to be over $10000 \mathrm{t} \mathrm{yr}^{-1}$ (Jones et al. 1997), totaling $250000 \mathrm{t}$ imported since the mid1990s (Arkush et al. 2006), for an industry that requires more than $55000 \mathrm{t}$ wet weight feed $\mathrm{yr}^{-1}$ (Hedrick et al. 2003). Most sardine used in Australia originate from fisheries in the Northwest Pacific Ocean, a region where VHSV is endemic in sardine populations (Hedrick et al. 2003). Concentrations of the virus in sardine from these fisheries may be low, especially in healthy, wild-caught fish (Arkush et al. 2006). Despite these large volumes of imported and likely VHSVinfected bait, there has been no indication of the spread of the virus among wild fish, salmonids or other pen-raised fish populations in Australia, although mass mortalities by herpesvirus of Australian pilchard Sardinops sagax have been reported (Murray et al. 2003). However, a key difference between the Chilean and Australian marine environments is water temperature: southern Chile is much cooler and thus potentially more conducive to VHSV infection compared to South Australia. In the XIIth region of Chile, the water temperature is always below $12^{\circ} \mathrm{C}$, ideal for potential VHSV infection and replication (Wolf 1988). In this virus-conducive environment, relatively small imported fish bait quantities $(<1000 \mathrm{t})$ may be important, particularly in the worst case scenarios $(\geq 16.7 \%$ VHSV-prevalence area), where far more than 50 southern hake in Chile could be expected to be infected per year. More research is needed to determine susceptibilities of different fish species in Chile and the potential VHSV route of transmission under local natural conditions.

\section{Effect of freezing}

Commercial freezing and thawing, as practiced with bait fish to preserve the fish and kill parasites, likely reduces concentrations of infectious virus up to $99.99 \%$. Arkush et al. (2006) demonstrated this level of reduction, although among examined sardine, $88 \%$ of the samples that were virus-positive prior to freezing were still positive upon re-examination after thawing. Thus, while freezing significantly reduces concentrations of VHSV, it does not eliminate the virus. Remaining concentrations after thawing in some fish were as great as $1 \times 10^{7} \mathrm{pfu} \mathrm{g}^{-1}$, similar to virus concentrations found in fish following experimental and natural exposures to VHSV (Meyers \& Winton 1995, Kocan et al. 1997, G. Traxler pers. comm.) and greater than the $2 \times 10^{5} \mathrm{pfu}$ $\mathrm{g}^{-1}$ needed to infect pike by the oral route (Ahne 1980). 


\section{Recommendations}

If VHSV were introduced into the local Chilean southern hake population, it is unknown how the virus might spread and what impacts might be anticipated. Mass mortality events among Pacific hake in North America due to VHS (Meyers et al. 1999) suggest that some negative impacts can be anticipated if infections were acquired by southern hake in Chile. The recent establishment in Chilean regulations of origin-based import standards and the assurances of proper freezing further reduce the potential infection of native fish in Chile. Future limitations on the amount of fish bait sold to small-scale fishermen could be evaluated to further reduce the already low potential risk of infecting wild salmonids in the fjords and channels in the south of Chile, although the small proportion of import bait used by this fishery suggest a low or no impact risk. If wild salmonids were to become infected, the more intimate contact of these fish with the pen-raised salmon (Soto et al. 2001) could lead to infection of these captive-bred populations (King et al. 2001b, Brudeseth \& Evensen 2002, Knuesel et al. 2003) with potentially detrimental consequences for salmon aquaculture.

Acknowledgements. The authors thank Dr. Marcelo Casali, Dr. Hernán Mansilla and Dr. Claudio Jara from Sernapesca, Chile, for their help and expertise. This study was partly supported by a grant from the US Department of Homeland Security.

\section{LITERATURE CITED}

Ahne W (1980) Experimentelle Egtvedvirusinfektion beim Hecht (Esox lucius L.). Tierärztl Umsch 35:225-229

Anonymous (1991) Council Directive 91/67/EEC of 28 January 1991 concerning the animal health conditions governing the placing on the market of aquaculture animals and products. Off J Eur Comm L046:0001-0018

Arkush KD, Mendonca HL, McBride AM, Yun S, McDowell TS, Hedrick RP (2006) Effects of temperature on infectivity and of commercial freezing on survival of the North American strain of viral hemorrhagic septicemia virus (VHSV). Dis Aquat Org 69:145-151

Atarhouch T, Ruber L, Gonzalez EG, Albert EM, Rami M, Dakkak A, Zardoya R (2006) Signature of an early genetic bottleneck in a population of Moroccan sardine (Sardina pilchardus). Mol Phylogenet Evol 39:373-383

Basurco B, Coll JM (1992) In vitro studies and in vivo immunisation with the first viral haemorrhagic septicaemia viruses isolated in Spain compared to international reference serotypes. Res Vet Sci 53:93-97

Brudeseth BE, Evensen O (2002) Occurrence of viral haemorrhagic septicaemia virus (VHSV) in wild marine fish species in the coastal regions of Norway. Dis Aquat Org 52: $21-28$

Collins MA (1999) Behavior observation on the scavenging fauna of the Patagonian slope. J Mar Biol Assoc UK 79 963-970 de Kinkelin P, Castric J (1982) An experimental study of the susceptibility of Atlantic salmon fry, Salmo salar L., to viral haemorrhagic septicaemia. J Fish Dis 5:57-65

Dixon PF, Feist S, Kehoe E, Parry L, Stone DM, Way K (1997) Isolation of viral haemorrhagic septicaemia virus from Atlantic herring Clupea harengus from the English Channel. Dis Aquat Org 30:81-89

Dixon PF, Avery S, Chambers E, Feist S and 7 others (2003) Four years of monitoring for viral haemorrhagic septicaemia virus in marine waters around the United Kingdom. Dis Aquat Org 54:175-186

Einer-Jensen K, Ahrens P, Forsberg R, Lorenzen N (2004) Evolution of the fish rhabdovirus viral haemorrhagic septicaemia virus. J Gen Virol 85:1167-1179

Elsayed E, Faisal M, Thomas M, Whelan G, Batts W, Winton J (2006) Isolation of viral hemorrhagic septicemia virus from muskellunge, Esox masquinongy (Mitchill), in Lake St. Clair, Michigan, USA reveals a new sub-lineage of the North American genotype. J Fish Dis 29:611-619

Gagné N, MacKinnon AM, Boston L, Souter B, Cook-Versloot M, Griffiths S, Olivier G (2007) Isolation of viral haemorrhagic septicaemia virus from mummichog, stickleback, striped bass and brown trout in eastern Canada. J Fish Dis 30:213-223

Gennari M, Tomaselli S (1988) Changes in aerobic microflora of skin and gills of Mediterranean sardine (Sardina pilchardus) during storage in ice. Int J Food Microbiol 6: 341-347

Goodwin A, Meyers RT, Money D (2004) Transmission of exotic fish viruses: the relative risks of wild and cultured bait. Fisheries 29:19-23

He P (1996) Bait loss from bottom-set longlines as determined by underwater observations and comparative fishing trials. Fish Res 27:29-36

Hedrick RP, Batts WN, Yun S, Traxler GS, Kaufman J, Winton JR (2003) Host and geographic range extensions of the North American strain of viral hemorrhagic septicemia virus. Dis Aquat Org 55:211-220

High WL (1980) Bait loss from halibut longline gear observed from a submersible. Mar Fish Rev 42:26-29

Iriarte A, Lobos G, Jacksic F (2005) Especies de vertebrados invasores en Chile y su control y monitoreo por agencias gubernamentales. Rev Chil Hist Nat 78:143-151

Jones JB, Hyatt AD, Hine PM, Whittington RJ, Griffin DA, Bax NJ (1997) Australasian pilchard mortalities. World J Microbiol Biotechnol 13:383-392

King JA, Snow M, Skall HF, Raynard RS (2001a) Experimental susceptibility of Atlantic salmon Salmo salar and turbot Scophthalmus maximus to European freshwater and marine isolates of viral haemorrhagic septicaemia virus. Dis Aquat Org 47:25-31

King JA, Snow M, Smail DA, Raynard RS (2001b) Distribution of viral haemorrhagic septicaemia virus in wild fish species of the North Sea, north east Atlantic Ocean and Irish Sea. Dis Aquat Org 47:81-86

Knuesel R, Segner H, Wahli T (2003) A survey of viral diseases in farmed and feral salmonids in Switzerland. J Fish Dis 26:167-182

Kocan R, Bradley M, Elder N, Meyers T, Winton JR (1997) North American strain of viral hemorrhagic septicemia virus is highly pathogenic for laboratory-reared Pacific herring. J Aquat Anim Health 9:279-290

López-Vázquez C, Bain N, Oliveira JG, Snow M, Raynard RS, Barja JL, Dopazo CP (2003) Characterization of VHSV isolates from Iberian origin and from the Flemish Cap by sequencing. In: Abstracts 11th Intl Conf EAFP Dis Fish Shellfish, St. Julians, Malta, 21-26 September, 2002, p 138A 
Lu Y, Loh PC (1992) Some biological properties of a rhabdovirus isolated from penaeid shrimp. Arch Virol 127: 339-343

Meyers TR, Winton J (1995) Viral hemorrhagic septicemia virus in North America. Annu Rev Fish Dis 5:3-24

Meyers TR, Short S, Lipson K, Batts WN, Winton JR, Wilcock J, Brown E (1994) Association of viral haemorrhagic septicaemia virus with epizootic haemorrhages of the skin in Pacific herring Clupea harengus pallasi from Prince William Sound and Kodiak Island, Alaska, USA. Dis Aquat Org 19:27-37

Meyers TR, Short S, Lipson K (1999) Isolation of the North American strain of viral hemorrhagic septicemia virus (VHSV) associated with epizootic mortality in two new host species of Alaskan marine fish. Dis Aquat Org 38:81-86

Mortensen HF, Heuer OE, Lorenzen N, Otte L, Olesen NJ (1999) Isolation of viral haemorrhagic septicaemia virus (VHSV) from wild marine fish species in the Baltic Sea, Kattegat, Skagerrak and the North Sea. Virus Res 63: 95-106

Murray AG, O'Callaghan M, Jones B (2003) A model of spatially evolving herpesvirus epidemics causing mass mortalities in Australian pilchard Sardinops sagax. Dis Aquat Org 54:1-14

OIE (Office international des épizooties) (2001) International aquatic animal health code: fish, molluscs and crustaceans, 4th edn. Office international des épizooties, Paris

Parrish R, Serra R, Grant W (1989) The monotypic sardine, Sardina and Sardinops: their taxonomy, distribution, stock structure, and zoogeography. Can J Fish Aquat Sci 41: $414-422$

Editorial responsibility: Julie Bebak, Auburn, Alabama, USA
Sierpe J, Sanhueza A (2003) Caracterización del Sector Pesquero: XII Región de Magallanes y Antártica Chilena. Servicio Nacional de Pesca (Sernapesca), Valparaíso

Skall HF, Olesen NJ, Mellergaard S (2005a) Prevalence of viral haemorrhagic septicaemia virus in Danish marine fishes and its occurrence in new host species. Dis Aquat Org 66:145-151

Skall HF, Olesen NJ, Mellergaard S (2005b) Viral haemorrhagic septicaemia virus in marine fish and its implications for fish farming: a review. J Fish Dis 28:509-529

Smail DA (2000) Isolation and identification of Viral Haemorrhagic Septicaemia (VHS) viruses from cod Gadus morhua with the ulcus syndrome and from haddock Melanogrammus aeglefinus having skin haemorrhages in the North Sea. Dis Aquat Org 41:231-235

Soto D, Jara F, Moreno C (2001) Escaped salmons in the Inner Seas, Southern Chile: facing ecological and social conflicts. Ecol Appl 11:1750-1762

Stone DM, Way K, Dixon PF (1997) Nucleotide sequence of the glycoprotein gene of viral haemorrhagic septicaemia (VHS) viruses from different geographical areas: a link between VHS in farmed fish species and viruses isolated from North Sea cod (Gadus morhua L.). J Gen Virol 78 (6): $1319-1326$

Voulgaridou P, Konstantinos S (2003) Trends in various biological parameters of the European sardine, Sardina pilchardus (Walbaum, 1792), in the Eastern Mediterranean Sea. Sci Mar 67:269-280

Wolf K (1988) Viral hemorrhagic septicemia. In: Fish viruses and fish viral diseases. Cornell University Press, Ithaca, NY, p 217-249

Submitted: October 7, 2006; Accepted: August 13, 2007

Proofs received from author(s): January 21, 2008 